\title{
HUBUNGAN MANAJEMEN PELAKSANAAN PEMANTAUAN PERTUMBUHAN TERHADAP PARTISIPASI MASYARAKAT DALAM KEGIATAN POSYANDU DI DUSUN O3 DESA MANISLOR
}

\author{
${ }^{1}$ Nadia Aimatun Nisa, ${ }^{1}$ Popy Viranti, ${ }^{1}$ Donasyhafira Bella Sayekti, ${ }^{2}$ Indra Surya Permana, \\ ${ }^{I}$ STIKes Mahardika Cirebon, Cirebon, Indonesia aimatunnadia@ gmail.com \\ ${ }^{I}$ STIKes Mahardika Cirebon, Cirebon, Indonesia popyviranti@gmail.com \\ ${ }^{2}$ Universitas Nahdlatul Ulama Cirebon, Cirebon, Indonesia indra@unucirebon.ac.id
}

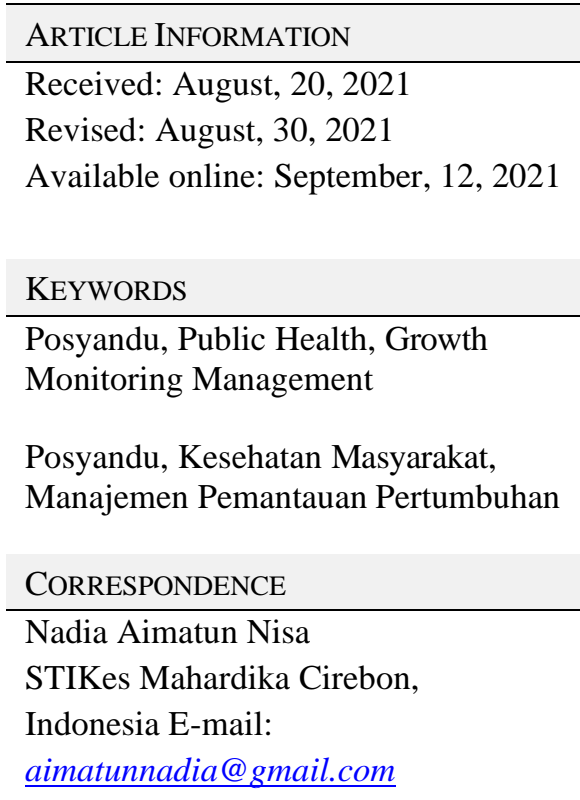

ARTICLE INFORMATION

Revised: August, 30, 2021

\begin{abstract}
Posyandu is a form of Community-Based Health Efforts (UKBM) which is managed and organized from, by, for and with the community in carrying out community health development, community empowerment and providing convenience for the community in obtaining basic health services to accelerate the reduction of maternal and infant mortality. (Ministry of Health, 2011). In general, this study aims to determine the relationship between management and implementation of growth and development monitoring on the achievement of the presence of mothers and children under five at the Posyandu Dusun 03 Manislor Village, Jalaksana District. The method used in collecting data in this research is a qualitative method. Posyandu Dusun 03 Manislor Village, community participation in participating in posyandu activities is quite good, because the number of visits every month reaches $70.5 \%$ - $88.2 \%$ although it often goes up and down, but the number of visits by mothers and toddlers to posyandu has never been $<50 \%$. Growth monitoring management in terms of the management system as described includes elements (Input, Process, Output) and includes 6M elements (Man, Money, Material, Machine, Method, Market). The lack of participation of mothers in posyandu can result in low monitoring of growth and development in toddlers and is closely related to the facilities and infrastructure available for growth monitoring activities.
\end{abstract}

\begin{abstract}
ABSTRAK
Posyandu adalah salah satu bentuk Upaya Kesehatan Berbasis Masyarakat (UKBM) yang dikelola dan diselenggarakan dari, oleh, untuk dan bersama masyarakat dalam melaksanakan pembangunan kesehatan masyarakat, pemberdayaan masyarakat dan memberikan kemudahan untuk masyarakat dalam memperoleh pelayanan kesehatan dasar untuk mempercepat penurunan angka kematian ibu dan bayi (Kementerian Kesehatan, 2011). Penelitian ini secara umum bertujuan untuk mengetahui hubungan manajemen dan pelaksanaan pemantauan tumbuh kembang terhadap pencapaian kehadiran ibu dan balita di posyandu Dusun 03 Desa Manislor Kecamatan Jalaksana. Metode yang digunakan dalam pengumpulan data penelitian ini adalah metode kualitatif.. Posyandu Dusun 03 Desa Manislor, partisipasi masyarakat dalam mengikuti kegiatan posyandu tergolong baik, karena jumlah kunjungan setiap bulannya mencapai 70,5\% - 88,2\% meskipun sering kali naik turun, namun jumlah kunjungan ibu dan balita ke posyandu tidak pernah $<50 \%$. Manajemen pemantauan pertumbuhan ditinjau dari sistem manajemen seperti dijelaskan mencakup unsur- unsur (Input, Proses, Output) serta mencakup unsur-unsur 6M (Man, Money, Material, Machine, Method, Market). Kurangnya partisipasi ibu di posyandu dapat mengakibatkan rendahnya pemantauan tumbuh kembang pada balita dan erat kaitannya dengan sarana dan prasarana yang tersedia untuk kegiatan pemantauan pertumbuhan.
\end{abstract}




\section{PENDAHULUAN}

\section{Latar Belakang}

Di era globalisasi, Indonesia sangat fokus untuk memajukan negaranya, dengan menciptakan masyarakat yang sehat, maju dan sejahtera. Kemajuan telah terjadi di segala bidang ilmu yang telah menghasilkan prestasi positif, terutama dalam ilmu dan teknologi kedokteran yang dapat meningkatkan kualitas kesehatan balita yang pada akhirnya berdampak pada meningkatnya jumlah balita dan tumbuh kembang anak. Oleh karena itu, dalam mengatasi permasalahan tersebut Program posyandu sangat dibutuhkan dimana posyandu dijadikan sebagai pusat kegiatan ibu-ibu dalam upaya pemenuhan pelayanan kesehatan bagi balita dan keluarga berencananya.

Posyandu adalah salah satu bentuk Upaya Kesehatan Berbasis Masyarakat (UKBM) yang dikelola dan diselenggarakan dari, oleh, untuk dan bersama masyarakat dalam melaksanakan pembangunan kesehatan masyarakat, pemberdayaan masyarakat dan memberikan kemudahan untuk masyarakat dalam memperoleh pelayanan kesehatan dasar untuk mempercepat penurunan angka kematian ibu dan bayi (Kementerian Kesehatan, 2011). Menurut Kementerian Kesehatan, tujuan didirikannya posyandu adalah untuk mempercepat penurunan angka kematian bayi, balita dan angka kelahiran, serta meningkatkan kemampuan masyarakat untuk mengembangkan kesehatan dan kegiatan penunjang lainnya, sesuai kebutuhan.peningkatan dari 6,9\% menjadi $8,5 \%$, Prevalensi dari penderita Diabetes Mellitus cenderung meningkat pada perempuan sebesar $(1,8 \%)$. sedangkan berdasarkan diagnosa dokter meningkat dari $1,5 \%$ menjadi $2 \%$ pada tahun 2018. (Kementrian Kesehatan, 2018).

Cakupan pelaksanaan pemantauan pertumbuhan di Indonesia masih cukup rendah. Frekuensi pemantauan pertumbuhan anak usia 6- 59 bulan dalam 6 bulan terakhir pada tahun 2013 bahwa frekuensi penimbangan $\geq 4$ kali menurun dari tahun 2007 yaitu dari $45,4 \%$ menjadi $44,6 \%$. Sedangkan anak yang tidak pernah ditimbang meningkat dari $25,5 \%$ (2007) menjadi 34,3\% (Kemenkes, 2013).

Berdasarkan penelitian pendahuluan di Dusun 03 Desa Manislor, Kecamatan Jalaksana, Kabupaten
Kuningan pada tahun 2020 diketahui bahwa jumlah partisipasi ibu dan balita yang hadir mengalami penurunan drastis dari tahun 2019 akibat situasi pandemi yang menyebabkan kegiatan posyandu tertunda sehingga partisipasi ibu dan balita $>50 \%$. Pada tahun 2021 kegiatan posyandu kembali aktif. Tetapi partisipasi ibu dan balita tetap naik turun dan dengan rata-rata peserta Posyandu sebesar $70,5 \%-88,2 \%$. Meskipun menurut Indikator pembangunan posyandu berdasarkan Kementerian Kesehatan (2011), jumlah Partisipasi peserta posyandu sudah diatas 50\%, namun jumlah kehadiran peserta tetap naik turun dan tidak menentu.

Penelitian ini secara umum bertujuan untuk mengetahui hubungan manajemen dan pelaksanaan pemantauan tumbuh kembang terhadap pencapaian kehadiran ibu dan balita di posyandu Dusun 03 Desa Manislor Kecamatan Jalaksana.

\section{METODE PENELITIAN}

Penelitian dilakukan di Posyandu Dusun 03 Desa Manislor, Kecamatan Jalaksana, Kabupaten Kuningan, Jawa Barat. Penelitian ini bertujuan untuk mendapatkan data tentang bagaimana partisipasi masyarakat dalam kegiatan Posyandu di Dusun 03 Desa Manislor.

Metode yang digunakan dalam pengumpulan data penelitian ini adalah metode kualitatif. Kegiatan penelitian difokuskan untuk menganalisis tingkat partisipasi masyarakat dalam kegiatan Posyandu dan apa yang menjadi kendala masyarakat untuk mengikuti dan melaksanakan kegiatan Posyandu. Subyek penelitian dalam penelitian ini adalah Kader Posyandu dan Masyarakat.

Penelitian ini dilakukan melalui identifikasi pengamatan penulis terhadap kegiatan yang dilakukan oleh Posyandu Dusun 03 Desa Manislor, Kecamatan Jalaksana, Kabupaten Kuningan, Jawa Barat. Instrumen yang digunakan adalah observasi, dan wawancara. Data hasil wawancara kemudian dianalisis oleh penulis melalui reduksi data, penyajian atau penyajian data dan penarikan kesimpulan.

\section{HASIL DAN PEMBAHASAN}

\section{Partisipasi Kehadiran Masyarakat Dalam Posyandu}

Partisipasi Masyarakat adalah suatu keterliatan

masyarakat di semua tahapan proses perkembangan yang ada di dalam suatu kelompok masyarakat. (Sawa Suryana, 2010)

Partisipasi masyarakat di bidang kesehatan berarti keikutsertaan seluruh anggota masyarakat dalam memecahkan 
masalah kesehatan mereka sendiri. Di dalam hal ini, masyarakat sendirilah yang aktif memikirkan, merencanakan, melaksanakan, dan mengevaluasikan program- program kesehatan masyarakatnya. Institusi kesehatan hanya sekadar memotivasi dan Sehingga mengakibatkan pola hidup yang buruk atau tidak adanya pantangan dalam membimbingnya (Notoatmodjo, 2007) Berdasarkan hasil penelitian di Posyandu Dusun 03 Desa Manislor, partisipasi masyarakat dalam mengikuti kegiatan posyandu tergolong baik, karena jumlah kunjungan setiap bulannya mencapai $70,5 \%$ - 88,2\% meskipun sering kali naik turun, namun jumlah kunjungan ibu dan balita ke posyandu tidak pernah di $<50 \%$. Faktor yang mempengaruhi berkurangnya pertisipasi masyarakat ke posyandu diantaranya :

a) balita sakit,

b) balita berusia di atas 36 Bulan tidak lagi berunjung ke posyandu

Untuk meningkatkan partispasi kehadiran ibu balita dalam kegiatan posyandu, peran petugas puskesmas dan kader sangat diperlukan yaitu untuk selalu mengingatkan ibu balita mengenai jadwal posyandu.

\section{Manajemen Pelaksanaan}

\section{Pemantauan Pertumbuhan}

Manajemen kesehatan dalam pelaksanaan pemantauan pertumbuhan adalah aplikasi prinsip pengelolaan (input, process,output) dalam pemantauan pertumbuhan melalui kegiatan dan pelaksanaan posyandu, kegiatan pemantauan pertumbuhan di posyandu dapat berjalan dengan baik, sesuai prosedur (alat antropometri dan kader), teratur, penempatan orang-orang yang terbaik di setiap aktivitas posyandu (Suyadi, 2011).

Penilaian input manajemen pemantauan pertumbuhan adalah penilaian tahap awal pemantauan pertumbuhan. Masuk (Input) adalah sumber daya yang diperlukan dalam kegiatan pemantauan pertumbuhan termasuk kader posyandu, sarana dan prasarana posyandu seperti alat timbang, alat mengukur lingkar lengan atas (LLA), tablet besi, Kapsul Vitamin A, Buku Kesehatan Ibu dan Anak (KIA) atau Kartu Menuju Sehat (KMS), form pengumpulan data, pencatatan dan pelaporan, serta poster Formulir SKDN (Kementerian Kesehatan, 2011). Manajemen pemantauan pertumbuhan ditinjau dari sistem manajemen seperti dijelaskan mencakup unsur-unsur, yaitu :
1) Input

Sarana prasarana yang diperlukan untuk pemantauan pertumbuhan mencakup

a. Man (Tenaga)

Kader Posyandu merupakan tenaga pelaksanaan kegiatan Posyandu dan harus orang yang siap, mampu dan bersedia secara sukarela. Kader Posyandu di Dusun 03 Desa Manislor seluruhnya berjumlah 5 kader.

b. Money (Anggaran)

Dalam pelaksanaan kegiatan Posyandu, dana menjadi kebutuhan yang sangat penting untuk keberlangsungan Posyandu. Di Dusun 03 Desa Manislor, dana untuk kegiatan Posyandu berasal dari Desa, yang diberikan setiap 1 tahun sekali sebesar Rp 300.000,-, dengan alokasi biaya Rp 25.000,-

/bulan. Dana bantuan tersebut digunakan seluruhnya untuk biaya penyediaan PMT setiap bulan, dengan anggaran untuk setiap bayi/balita Rp 2.000,- /bulan/PMT.

c. Material (Bahan)

Material dalam Posyandu merupakan bahan yang digunakan untuk mencapai tujuan Posyandu. Bahan penunjang untuk Posyandu meliputi kelengkapan bahanbahan pendukung kegiatan Posyandu, antara lain : Kartu Menuju Sehat (KMS),Timbanan badan, , Buku KIA, balok SKDN, dan bahan makanan untuk PMT yang harus cukup tersedia baik dari segi kuantitas maupun dari segi kualitasnya.

d. Machine (Peralatan)

Machine dalam Posyandu merupakan alat- alat yang dibutuhkan dan digunakan untuk pelaksanaan kegiatan. Kelengkapan alat- alat pelengkap mempengaruhi kelancaran dan keberhasilan pelaksanaan Posyandu.Alatalat yang dibutuhkan, antara lain : dacin, LILA, mikrotoa, panjang badan, timbangan injak

e. Method (Metode)

Methode dalam Posyandu merupakan cara, sistem atau prosedur kerja yang digunakan dalam pelaksanaan Posyandu Sistem pelaksanaan Posyandu yang wajib dilaksanakan pada hari pelaksaanaan adalah sistem 5 meja. Selain sistem 5 meja memiliki program kegiatan yang menunjang keberhasilan Posyandu.

f. Market (Sasaran)

Market yang dimaksud dalam Posyandu adalah sasaran kegiatan dan proses penginformasian Posyandu kepada warga. Kemenkes (2011) menyebutkan bahwa sasaran utama Posyandu adalah bayi, anak balita, ibu hamil, ibu nifas, ibu menyusui dan Pasangan Usia Subur. Namun, dalam pelaksanaannya sasaran Posyandu Dusun 03 Desa Manislor belum mencakup sasaran yang diprioritaskan oleh Pemerintah. Sasaran Posyandu Dusun Penjalinan hanya bayi, balita, ibu hamil. 
Hasil penelitian pada input manajemen pelaksanaan pemantauan pertumbuhan di posyandu Dusun 03 Desa Manislor 2021, hanya mencapai $60 \%$. Hal ini menunjukan bahwa sarana prasarana pemantauan pertumbuhan yang tersedia disebagian besar posyandu sudah berfungsi dengan baik.

2) Proses

Komponen proses manajemen pelaksanaan pemantauan pertumbuhan terdiri dari 5 kegiatan, meliputi : kegiatan persiapan, kegiatan penimbangan, kegiatan penyuluhan, kegiatan paket pelayanan pertolongan gizi dan kesehatan, serta kegiatan yang wajib diterapkan pada hari pelaksanaan, Posyandu juga juga harus pelaporan dan rencana tindak lanjut.

Hasil dalam penelitian ini juga ditemukan bahwa kegiatan persiapan dan penyuluhan terutama dalam kegiatan penjangkauan dengan mengacu pada Kartu Menuju Sehat (KMS) untuk balita serta memobilisasi potensi masyarakat. Hal ini senada dengan Kasmita, dkk (2000) dalam Badawi (2014) dimana kegiatan persiapan kader yang belum maksimal, pencatatan menimbang hasil ke formulir register dan Kartu Menuju Sehat (KMS), penyuluhan yang belum diarahkan karena tidak ada peran tenaga kesehatan di posyandu Dusun 03 Desa Manislor, sehingga jika ingin dilakukan imunisasi atau pemberian vitamin harus ke Balai Desa dan ditentukan waktu khususnya sehingga menyebabkan proses tidak berjalan dengan baik.

3) Output

Output adalah keluaran kegiatan posyandu berupa cakupan hasil kegiatan penimbangan, pelayanan pemberian makanan tambahan, pelayanan imunisasi, pelayanan keluarga berencana dan penyuluhan. Hasil Output pada penelitian ini, hasil kegiatan penimbangan rata- rata berat badan

balita Naik dan $3,6 \%$ balita menderita Obesitas, pelayanan pemberian makanan tambahan terlaksana dengan baik, sehingga balita yang datang ke posyandu mendapatkan pemberian makanan tambahan, pelayanan imunisasi terlaksana dengan baik hampir $100 \%$ balita mendapatkan pelayanan imunisasi. Namun, pelayanan keluarga berencana dan penyuluhan masih belum berjalan, hal ini disebabkan oleh tidak adanya peran tenaga kesehatan di posyandu Dusun 03 Desa Manislor, sehingga diketahui bahwa untuk meningkatkan manajemen pelaksanaan pemantauan pertumbuhan menjadi lebih baik maka perlu ditingkatkan output manajemen pelaksanaan pemantauan pertumbuhan.

\section{Hubungan Manajemen Pelaksanaan Pemantauan Pertumbuhan Terhadap Partisipasi Masyarakat Dalam Kegiatan Posyandu}

Partisipasi kehadiran posyandu adalah sebagai upaya yang dilakukan dalam meningkatkan pertumbuhan balita. Kegiatan pemantauan pertumbuhan yang dilakukan setiap bulan di Posyandu mempunyai tujuan sebagai pelayanan gizi dan kesehatan dasar (Depkes, 2004). Kurangnya partisipasi ibu di posyandu dapat mengakibatkan rendahnya pemantauan tumbuh kembang pada balita. di samping itu. Kurangnya partisipasi ibu dalam posyandu erat kaitannya dengan sarana dan prasarana yang tersedia untuk kegiatan pemantauan. Pembinaan yang dilakukan di posyandu adalah pelayanan kader dan petugas kesehatan dalam pemantauan pertumbuhan. Pelayanan kader posyandu memegang peranan penting dalam kunjungan ibu ke posyandu. Pelayananan posyandu menyenangkan, ramah, serta memberikan informasi dan penyuluhan yang jelas dan mudah dipahami oleh ibu balita, dan dapat meningkatkan kesadaran, pelayanan keluarga berencana masih belum terlaksana di posyandu, dan penyuluhan masih belum terlaksana secara baik.

Dari hasil penelitian diatas, dapat ibu balita untuk membawa balita ke posyandu. Bila ibu balita puas dengan pelayanan yang diberikan oleh kader posyandu, Ia berusahah meluangkan waktunya untuk mengantar balita ke posyandu (Nurmayani, 2013).Banyaknya kader yang bertugas pada hari pelaksanaan posyandu juga dapat dijadikan indikasi apakah kegiatan pemantauan pertumbuhan berjalan lancar (Nusi, 2006). Berdasarkan penelitian Hayati (2000) dan Juarsa (2004) dalam Makmur (2009), dimana keterampilan kader memiliki hubungan yang signifikan meningkatkan cakupan penimbangan balita dengan memotivasi ibu balita untuk datang ke posyandu.

\footnotetext{
KESIMPULAN

Posyandu Dusun 03 Desa Manislor, partisipasi masyarakat dalam mengikuti kegiatan posyandu tergolong baik, karena jumlah kunjungan setiap bulannya mencapai 70,5\% - 88,2\% meskipun sering kali naik turun, namun jumlah kunjungan ibu dan balita ke posyandu tidak pernah di $<50 \%$. Faktor yang mempengaruhi berkurangnya pertisipasi masyarakat ke poyandu diantaranya :
} 
a) balita sakit,

b) balita berusia di atas 36 Bulan tidak lagi berunjung ke posyandu.

Manajemen pemantauan pertumbuhan ditinjau dari sistem manajemen seperti dijelaskan mencakup unsurunsur :

a) Input yang mencakup unsur (Man, Money, Material, Machine, Method, Market)

b) Proses

c) Output

Kurangnya partisipasi ibu di posyandu dapat mengakibatkan rendahnya pemantauan tumbuh kembang pada balita. di samping itu. Kurangnya partisipasi ibu dalam posyandu erat kaitannya dengan sarana dan prasarana yang tersedia untuk kegiatan pemantauan. Pembinaan yang dilakukan di posyandu adalah pelayanan kader dan petugas kesehatan dalam pemantauan pertumbuhan.

\section{DAFTAR PUSTAKA}

Kemenkes RI. 2010. Peraturan Menteri Kesehatan Republik Indonesia Tentang Penggunaan Kartu Menuju Sehat (KMS) Bagi balita. Direktorat Jenderal Bina Kesehatan Masyarakat. Jakarta

Erman, Imelda. 2010. Faktor-Faktor Yang Mempengaruhi Kunjungan Ibu Yang Mempunyai Balita Ke Posyandu Di Kelurahan Lubuk Tanjung Wilayah Kerja Puskesmas Permunas Kota Lubuklingau Jurnal Ilmiah Multi Science. Sekolah Tinggi Ilmu Kesehatan Siti Khadijah. Palembang.

Puja LM. Faktor-faktor Yang Mempengaruhi Keaktifan Posyandu (Karya Tulis Ilmiah). Semarang Universitas Diponegoro; 2007.

Ristanti, Idcha Kusuma, dkk. 2018. Tinjauan Pelaksanaan Posyandu Berdasarkan UnsurUnsur Manajamen (6M). Jurnal Pendidikan Kesehatan : Poltekkes Kemenkes Malang

Hs, Hastaty. 2015. Perilaku Kader Dalam Pemantauan Pertumbuhan Balita Di PuskesmasMandala Kecamatan Medan Tembung. Medan : Universitas Sumatera Utara.

Hidayati, Nurul. 2010. Faktor-faktor yang Berhubungan dengan Parsipasi Ibu Balita ke Posyandu d iKelurahan Rempoa Kecamatan Ciputat Timur Tangerang Selatan.Skripsi. UIN Syarif Hidayatullah Jakarta: Fakultas Kedokteran Dan Ilmu Kesehatan, 2011

Umma, Nurhasanah. 2018. Hubungan Manajemen Pelaksanaan Pemantauan Pertumbuhan
Terhadap Partisipasi Kehadiran Posyandu dan Atatus Gizi Balita Di Wilayah Kerja Puskesmas Tanjung Beringin Kecamatan Tanjung Beringin Skripsi. Politeknik Kesehatan 